\title{
Discussion on the Law of Hidden Interview and News Tort in the Context of Integration Media
}

Junmiao Shi*

Zhejiang Wanli University, Ningbo 315000, China. E-mail: 1211167813@qq.com

Abstract: The arrival of the media era has also brought about the diversity and novelty of news interview methods, and the controversial hidden interview is one of the important interview methods. In recent years, more and more journalists use implicit interviews to get the audience's attention, followed by a series of legal issues such as news infringement. Hidden interview as a double-edged sword, if not grasp the "degree" of interview, not only difficult to reveal the truth, often counterproductive, resulting in violations of privacy rights, therefore, how to avoid the hidden interview in the news practice of news infringement has become a problem that every journalist should ponder.

Keywords: Media Integration; Hidden Interview; News Infringement

\section{An overview of hidden interviews}

\subsection{Definition of implicit interviews}

Implicit interview is also called secret interview or secret visit, which is usually a way for journalists to reveal the facts that involve the public interest but are deliberately concealed by means of secretly filming or recording without the knowledge of the other party. The recessive interview includes three types: the public opinion supervision report which reveals the truth, the test type recessive interview, the hidden interview which reveals the natural state. This method of interview is only applicable to special occasions or special subjects, and should be authorized by the relevant departments to conduct interviews within the limits of legal and moral permission. The annual "3.15" party in our country usually takes the way of hidden interview to reveal the truth, which not only protects the public interest, but also avoids the risk of news infringement to the greatest extent.

\subsection{Characteristics of hidden interviews}

(1) The reporter's real identity is not disclosed. Reporters conceal their true identity and the purpose of the interview, in order to hide, understand the truth behind things, so as to obtain more valuable news content. For example, many news reports on food safety, reporters conceal their true identity to talk to stores, so that fake and inferior products and food safety hazards to the public, to protect the legitimate rights and interests of consumers.

(2) It's specific. Implicit interview is only suitable for a specific scene, a specific subject matter, not every news subject matter is suitable for the interview mode of implicit interview, only when the public interview can not obtain the authenticity of the news, it can use implicit interview, and it should also be approved and authorized by the relevant departments when using implicit interview.

(3) Authenticity. Hidden interview can make us get more real, more detailed news content, authenticity is the life of news, but also the essence of news regulation, only adhere to the truth, our news reports can be more powerful, news media can be more authoritative and vitality.

\subsection{Need for hidden interviews}

\section{Copyright (C) 2020 Junmiao Shi}

doi: $10.18686 / \mathrm{mcs} . v 2 \mathrm{i} 2.1303$

This is an open-access article distributed under the terms of the Creative Commons Attribution Non-Commercial License (http://creativecommons. org/licenses/by-nc/4.0/), which permits unrestricted non-commercial use, distribution, and reproduction in any medium, provided the original work is properly cited. 
(1) Implicit interview is beneficial to protect citizens' right to know and supervise public opinion. The right to know and the right to supervise public opinion are the basic rights granted to citizens by our constitution and one of the functions of the news media itself. Hidden interviews are often more real and can guarantee citizens' right to know. The essence of public opinion supervision is public opinion, implicit interview in exposing corruption and fake and inferior products, public opinion supervision can play a great role, make public power more transparent, let public power better serve the people.

(2) Implicit interviews contribute to the authenticity of the news. Hidden interview is to interview without the knowledge of the interviewee, and the information obtained is more accurate, which makes the news more authentic and increases the persuasion of the news. Meet the needs of the public for the truth and the right to the truth.

(3) Hidden interview is conducive to improving the competitiveness of the media. Hidden interviews enable journalists to obtain first-hand exclusive information, and the authenticity and accuracy of their information can attract the attention and attention of the audience, which can help to improve the competitiveness of the media in the competition of the industry.

\section{News infringement in invisible interview}

\subsection{Implicit interviews may violate the privacy of the press}

In order to obtain exclusive news, many journalists usually enter the private life of the parties to carry out illegal investigations, which not only seriously affects the normal life of the parties, but also reveals the personal information and the current situation of life of the parties, which brings serious trouble to the parties and infringes the privacy rights of the parties to the news.

\subsection{Recessive interviews may also violate the right to portrait of a journalist}

According to the law of our country, citizens have the right to own their own portraits, and citizens also have the right to prohibit others from using their own exclusive portraits without authorization. The act of secretly filming and recording a hidden interview exposes the portrait of the person interviewed without the knowledge and permission of the person concerned, which has violated the protection of the right of citizens to portrait.

\subsection{Recessive interviews also violate the right to reputation of the press}

In the hidden interview, the reporter often induces the interview to the party in order to obtain the truth of the news. Because of the individual behavior of the reporter, it is likely to affect the public's objective and fair evaluation of the news party, cause the public to insult and slander the party concerned, and violate the right of reputation of the party concerned.

\section{How to avoid news tort}

Hidden interview has its own advantages, but a careless will go from safeguarding social interests to infringing on social interests, so how to avoid news infringement in news practice is particularly important. We can avoid news infringement from the following aspects.

\subsection{Journalists should abide by relevant laws and grasp the degree of interview}

Hidden interview is an indispensable way of interview in the news, in order to avoid the news infringement journalists should abide by the law, for some cases involving pornography, drugs and other violations of the law, journalists can not try the law. At the same time, journalists should also grasp the "degree" of the interview, involving state secrets, trade secrets, personal privacy, juvenile delinquency and the privacy of citizens who have nothing to do with the public interest should not use hidden interviews, so as to avoid the occurrence of illegal acts that violate the right to privacy.

\subsection{Journalists should strengthen their professional qualities and enhance their sense of social responsibility}

In order to avoid the infringement of news, we should start from the reporter himself, and the reporter himself should make it clear that the purpose of the hidden interview is to safeguard the public interest of the society, to expose 
the problem and to solve the problem, rather than to recreate the facts on the basis of the original facts. In the process of interview, the reporter can not actively induce the parties to lure them to commit crimes, and should give the parties humanistic care, fully consider the impact on the parties after the broadcast of the program, and weigh the pros and cons. For journalists who do not abide by professional ethics and cause news infringement, the news media should set up a blacklist and no longer engage in news work.

\subsection{The state shall strengthen the construction of the rule of law and improve the corresponding laws and regulations}

It is not only necessary for journalists to strengthen their professional quality and strictly demand themselves to avoid news infringement, but also for the state to strengthen the construction of the legal system and improve the relevant laws and regulations. In our country, there has never been a law on journalism, resulting in no perfect law to restrict journalism. News work has its own particularity, if journalists do not grasp the "degree" in the hidden interview, it is easy to lead to the occurrence of news infringement. At the same time, journalists in the interview, personal safety is often threatened, beaten, accidents often occur. Without a sound law as a safeguard, it is difficult to strike a balance between the interests of journalists and the public. Therefore, the government should speed up the introduction of news laws to protect the two-way interests of journalists and the public.

\subsection{The public shall cooperate with the media to monitor and prevent press abuse}

The prevention of news infringement requires the joint efforts of all sectors of society, the public should correctly understand the supervision of public opinion of the media, and actively and reasonably safeguard their legitimate interests. The news media should serve the people, not above them, not above the law. When the legitimate rights and interests of the public are infringed, measures should be taken in time to protect their own rights and interests. Only by preventing the occurrence of news infringement, the media coverage will be deeply rooted in the hearts of the people, and the news will be more valuable.

\section{Conclusion}

When he was deputy editor-in-chief of the People's Daily newspaper, Bohua Mi said: "We should do and can do some things, we to the motherland with unlimited loyalty to the people, no one can not but admire and look up to." Implicit interview has both advantages and disadvantages. Making good use of implicit interview can help to reveal the truth, safeguard social interests, safeguard the legitimate rights and interests of citizens, and at the same time help to increase the core competitiveness of the media. If journalists can not grasp the "degree" of interviews, it will cause news infringement. And news infringement needs the joint efforts of the news media, the public and the government to provide the audience with more real and accurate news.

\section{References}

1. Tian L. Legal discussion on covert interview and news infringement under the background of integrated media (in Chinese). Public Communication of Science Technology 2020; 12(1): 141-142.

2. Tan Y. Research on implicit interview news infringement (in Chinese). Modern Economic Information 2015; (12): 314.

3. Zeng X. TV interview (in Chinese). Communication University of China Press 2010.

4. Duan W, Duan Q. A study on the grasping of "degree" by TV news reporters in covert interview (in Chinese). Today's Massmedia 2014; 22(8): 175-176. doi: 10.3969/j.issn.1672-8122.2014.08.080.

5. Zhang Y. On the advantages and disadvantages of hidden interview and principles (in Chinese). Radio \& TV Journal 2015; (2): 85-86. doi: 10.3969/j.issn.1674-246X.2015.02.055.

6. Xu C. Journalist's legal accomplishment and news report infringement (in Chinese). Youth Journalist 2017; (6): 56-57.

7. Yang C. How to protect the interviewee in the implicit interview (in Chinese). Modern Audio-Video Arts 2009; (S1).

8. Gui L. Ethical reflections on recessive interview in TV news (in Chinese). Journal of Beijing Vocational College of Political Science and Law 2014; (4).

9. Hui L, Shi Y. Legal thinking on recessive interview (in Chinese). Journalism Knowledge 2013; (6).

10. Hu L. Reporter's role rights and professional responsibilities in covert interview (in Chinese). TV Research 2000; (10). 